\title{
Detection of poliovirus by ICC/qPCR in concentrated water samples has greater sensitivity and is less costly using BGM cells in suspension as compared to monolayers
}

Helene B Balkin*, Aaron B Margolin

\begin{abstract}
The integrated cell culture quantitative reverse transcriptase PCR (ICC/qRT-PCR) method is used in our lab to detect enteroviruses in environmental waters. Typically we utilize monolayers of 3 cell lines; buffalo green monkey kidney (BGM), human colonic carcinoma (CACO-2) and African rhesus monkey kidney (MA104) with the intent of providing one or more permissive hosts to a wide range of enteroviruses. In this study the BGM cell line was used to compare poliovirus infectivity in conventional monolayer cultures to BGM cells in suspensions. Propagated virus was subsequently amplified by qRT-PCR. Our PCR data showed lower cycle threshold (Ct) values in the suspensions which corresponded to a higher rate of infectivity than that observed in the monolayers. The difference in $\mathrm{Ct}$ values was determined statistically significant by One-way ANOVA (0.000). Infecting BGM cells in suspensions required less hands-on time, less chance of contamination and was more cost effective than utilizing the conventional monolayer technique.
\end{abstract}

\section{Findings}

Viral infection is suspected in $50 \%$ of all acute gastrointestinal illness [1] with the public being at greatest risk acquiring infection through wastewaters that contaminate drinking water sources, recreational waters and shellfish harvesting waters [2].

ICC/qRT-PCR is a proven method for the rapid detection of infective enteroviruses in environmental waters $[3,4]$. With this technique viruses, which are generally present in low numbers, are propagated in monolayers of a host cell line which increases the PCR target. Little published research is available using cell culture systems other than monolayers to screen environmental samples $[5,6]$. One study reported the development of a BGM shaker culture where the cells were adapted to a suspension culture by serial passaging and using special medium and a gyratory shaker. Infectivity was compared between the adapted cells and BGM monolayers by inoculating with poliovirus 1,2 and 3 (as well as other

\footnotetext{
* Correspondence: hbalkin@unh.edu
Molecular, Cellular and Biomedical Sciences Department, University of New

* Correspondence: hbalkin@unh.edu Hampshire, Durham NH USA
}

(c) 2010 Balkin and Margolin; licensee BioMed Central Ltd. This is an Open Access article distributed under the terms of the Creative Commons Attribution License (http://creativecommons.org/licenses/by/2.0), which permits unrestricted use, distribution, and reproduction in any medium, provided the original work is properly cited. forming units per $\mathrm{mL}(\mathrm{PFU} / \mathrm{mL})$ than the monolayers [6]. In another (clinical) study, cells were infected with herpes simplex virus (HSV) in what was described as a simultaneous seeding and infection (suspensioninfection) method which yielded a mean time to diagnosis of 1 day. This method became routinely used in the authors' laboratory because of its ease, sensitivity and timeliness [7]. Here we describe a comparable suspension-infection technique for detecting viruses in environmental samples that doesn't involve adapting and maintaining cells in suspension or the manipulations and procedural steps associated with conventional monolayer cell culture.

For this study the BGM cell line was chosen to demonstrate proof of concept due to its high susceptibility to enteroviruses in water samples $[5,6,8]$ and the concomitant use of poliovirus as a standard experimental model. In addition enumeration of poliovirus in BGM monolayers is easily accomplished via neutral red plaque assay. viruses). The suspensions showed higher $\log 10$ plaque 
Three experiments were performed using in house BGM cells at passage number 94. In each trial cells were seeded into six Corning $\mathrm{T} 150 \mathrm{~cm}^{2}$ culture flasks with growth medium containing 43\% Lebowitz L-15 modified medium (Sigma), 27\% Eagle's Minimal Essential Medium (MEM), 24\% HEPES (Fisher), 4\% sodium bicarbonate (Sigma), 2\% (w/v) L-glutamine (Sigma), 1\% non-essential amino acids, $1 \%$ antibiotic/antimycotic (Cellgro), 1\% kanamycin sulfate (Cellgro) and heat treated $5 \%(\mathrm{v} / \mathrm{v})$ fetal bovine serum (FBS) (JRH Biosciences). The cells were incubated at $37^{\circ} \mathrm{C}$ in a closed system until confluent monolayers of $\sim 1.5 \times 10^{7}$ total cells were observed. All of the monolayers were washed three times with phosphate buffered saline (PBS) (Sigma) prior to manipulation. Three of the monolayers were detached with $10 \mathrm{~mL}$ of trypsin EDTA (Cellgro) and transferred to corresponding $50 \mathrm{~mL}$ polypropylene (pp) conical tubes (Sarstedt). MEM supplemented with $2 \%$ FBS was added to each tube for a volume of $34 \mathrm{~mL}$. The monolayers and suspensions were immediately inoculated with a mock sample which was prepared by dissolving 10\% beef extract (BE) (Becton Dickinson) in 4 liters of deionized (DI) water at neutral $\mathrm{pH}$. When the BE was thoroughly suspended the sample was concentrated by organic flocculation [9] for a final volume of $20 \mathrm{~mL}$. Each sample was inoculated with $1 \%$ of $100 \mathrm{X}$ antibiotic/antimycotic and $0.1 \%$ of 50 ug per $\mathrm{mL}$ of gentamicin sulfate and incubated at $37^{\circ} \mathrm{C}$ for 2 hours. Post incubation the samples were stored at $-80^{\circ} \mathrm{C}$.

Prior to spiking the concentrated samples were quickly thawed at $37^{\circ} \mathrm{C}$. They were combined for a total volume of $200 \mathrm{~mL}$ and then spiked with $8.5 \times 10^{6} \mathrm{PFU} /$ $\mathrm{mL}$ poliovirus type 1 strain LSc-1 (PV 1) which was enumerated by a neutral red plaque assay. Six $\mathrm{mL}$ of the sample which contained 10 PFU PV1 was added to each of the three monolayers and three suspensions. The monolayers were incubated at $37^{\circ} \mathrm{C}$ for $80 \mathrm{~min}$ to allow for adsorption of the PV1. They were subsequently returned to the safety hood for the addition of MEM supplemented with $2 \%$ FBS and then returned to the incubator. The suspensions were gently swirled and the tubes were placed horizontally between Styrofoam strips with the capped end slightly elevated in a $37^{\circ} \mathrm{C}$ incubator.

All of the controls for the monolayers and suspensions were prepared in triplicate. Negative controls consisted of MEM supplemented with 2\% FBS, unspiked concentrated sample, and PBS. The positive controls were inoculated with 100 PFU of poliovirus with the Time = 0 hour $(\mathrm{T}=0)$ control being immediately frozen at $-80^{\circ} \mathrm{C}$.

No manual counts were performed on the monolayers or suspensions immediately before or after inoculation. Prior research by Hoyt et al. [10] demonstrated that it took 24-48 h for 100,000 BGM cells to double in density, therefore, no appreciable increase in number would occur. Future work using cells with densities less well characterized will be counted just prior and post inoculation.

The monolayers and suspensions were observed the following day by inverted phase contrast microscopy. As expected the monolayers were unaffected, where as in the tubes, cellular debris and both attached cells and suspended cells were seen. By day 3 post infection, partial monolayers in the flasks were observed along with rounded up and floating cells. In the pp tubes, a layer of cells was still attached and many floating cells and clumps of cellular debris were observed. On day 6 the flasks had mostly floating cells with some attached cells remaining. The tubes showed mostly CPE with few attached cells. All flasks and tubes were frozen on day 6 at $-80^{\circ} \mathrm{C}$ and stored until the RNA extraction procedure was performed. Because of the highly lytic nature of poliovirus type 1 strain LSc-1 and the duration of the experiment only 1 freeze/thaw was performed. However future work utilizing different cell lines and viruses may require more freeze/thaw cycles.

The samples were rapidly thawed prior to nucleic acid extraction using Qiagen's QIAamp DNA mini blood columns with the following changes: the volume of ethanol was increased from $200 \mathrm{uL}$ to $230 \mathrm{uL}$ and the elution Buffer AE was decreased from $200 \mathrm{uL}$ to $60 \mathrm{uL}$. These columns are used in our lab to extract and co-purify DNA and RNA viruses from cell lysates. One $\mathrm{mL}$ aliquots were spun in microcentrifuge tubes to pellet cellular debris. Two hundred microliters of the supernatant was processed and the nucleic acid was stored at $-20^{\circ} \mathrm{C}$.

qRT-PCR was performed on the Applied Biosystems (AB) 7300 real-time machine using the TaqMan One Step RT-PCR kit (AB). Each reaction contained $5 \mathrm{uL}$ of RNA template and a panenterovirus set of primers and probe $(A B)$. The primers and probe targeted the highly conserved $5^{\prime}$ untranslated region of the genome [11]. The 5' and 3' end of the probe were labeled with reporter 6-carboxyfluorescein (FAM) and quencher 6-carboxytetramethylrodamine (TAMRA) respectively as depicted in Table 1. Serial 10 fold dilutions of stock

\begin{tabular}{|c|c|c|}
\hline $\begin{array}{l}\text { Forward } \\
\text { primer }\end{array}$ & $\begin{array}{l}5^{\prime}- \\
\text { CCTCCGGCCCCTGAATG-3' }\end{array}$ & $\begin{array}{l}\text { 197-bp highly } \\
\text { conserved }\end{array}$ \\
\hline & & 5'untranslated region \\
\hline Reverse primer & \multicolumn{2}{|l|}{$\begin{array}{l}5^{\prime}- \\
\text { ACCGGATGGCCAATCCAA-3' }\end{array}$} \\
\hline Probe & \multicolumn{2}{|c|}{ 5'-6FAM-TACTTTGGGTGTCCGTGTTC-TAMRA-3' } \\
\hline
\end{tabular}




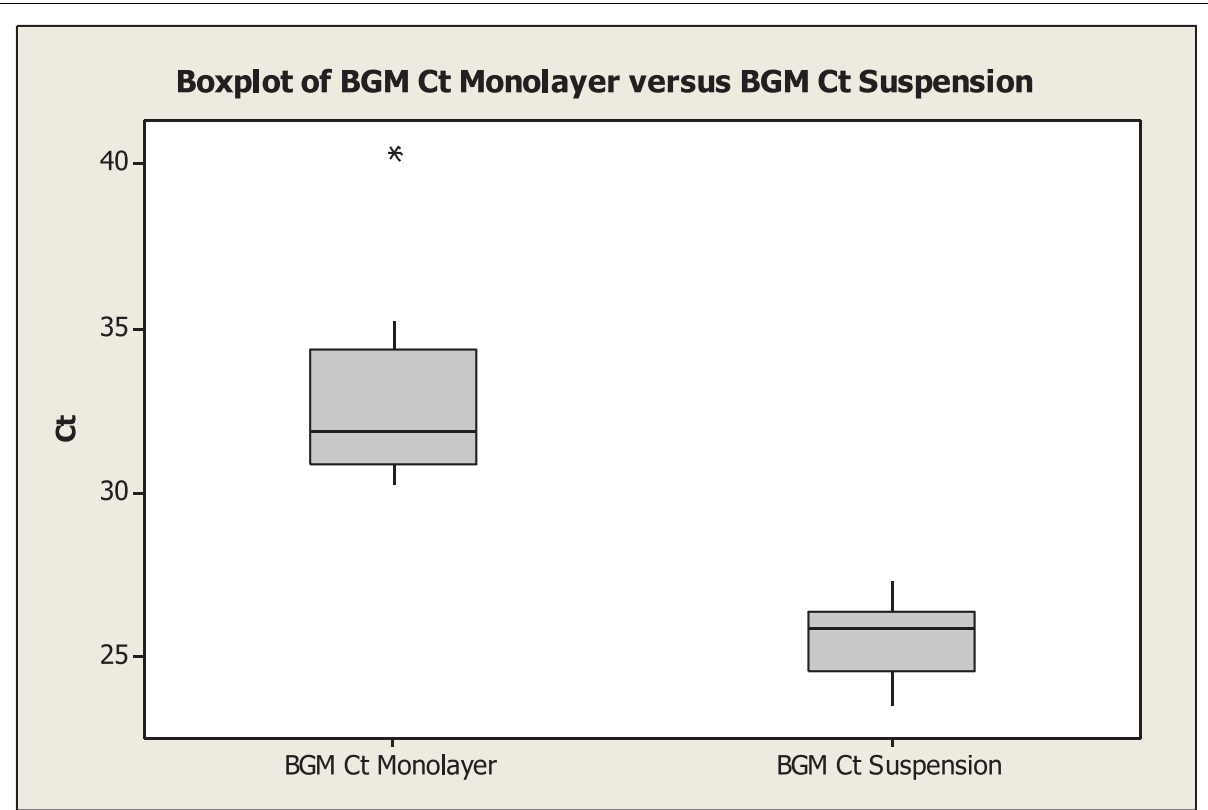

Figure 1 Comparison of ICC/q RT PCR cycle threshold (Ct) values of BGM monolayers infected with 10 PFU of poliovirus type 1 (strain LSc-1) to similarly infected BGM suspensions in $\mathbf{5 0 ~} \mathbf{~ m L ~ p p ~ t u b e s ~ o n ~ d a y ~} \mathbf{6}$. Each boxplot represents 3 trials run in triplicate. The average Ct values were 32.17 and 25.51 for the monolayers and suspensions respectively. One-way ANOVA was applied to interpret the Ct data. The groups were determined to be statistically significant different ( $p 0.000)$.

poliovirus $1 \mathrm{LSc}-1$ of $8.5 \times 10^{6} \mathrm{PFU} / \mathrm{mL}$ exhibited a detection limit of 0.425 PFU (data not shown).

All controls and experimental groups were run in triplicate (neg, pos, and $\mathrm{T}=0$ hour not shown). The thermal profile was $48^{\circ} \mathrm{C}$ for $45 \mathrm{~min}, 95^{\circ} \mathrm{C}$ for $10 \mathrm{~min}, 45$ cycles of $94^{\circ} \mathrm{C}$ for $15 \mathrm{sec}$ and $55^{\circ} \mathrm{C}$ for $1 \mathrm{~min}(\mathrm{AB})$.

A boxplot was constructed from the $\mathrm{Ct}$ data (see Figure 1).

The ICC-qRT-PCR method allows low virus concentrations to be propagated to increase target nucleic acid. Traditional cell culture methods employ only the monolayer 2D arrangement which in this study showed lower levels of infection compared to the cells in a suspension or $3 \mathrm{D}$ configuration. To clarify, this was not a true suspension culture in that there was no special medium and no mechanical means to stop the cells from attaching. Upon inoculation however, the cells were in a 3D form enveloped in sample and medium. By placing the tubes horizontally the cells were prevented from pooling at the bottom and instead remained mostly in suspension with some attached to the sides. It was demonstrated in our lab (unpublished) that BGM cells in suspension on day 6 are viable. An aliquot of suspension was seeded into a flask where a monolayer growth pattern was formed.

Research by Goldstein et al. proved that cells in a true suspension or $3 \mathrm{~d}$ configuration aids in poliovirus (and other viruses) infection. In a clinical setting Luker et al. demonstrated that even in low numbers virus infection in a suspension-infection method is detected sooner than the monolayer method and that it was not imperative that cells remain in suspension for infection to progress. Similarly, our study displayed higher PV1 infection in cells that were in suspension compared to the monolayer conformation. Trypsinization immediately before the suspensions were inoculated may have increased yield however Goldstein et al. did not add trypsin to the suspensions which showed a higher rate of infection.

The benefits of using the tubes were the lower risk of contamination, less manipulation required, and the vast cost difference between culture flasks and pp tubes.

In the future we expect to study adenovirus 40, 41, astrovirus, and rotaviruses which are also found in environmental waters and compare monolayers and suspensions by ICC/qPCR, and qRT-PCR

\section{Acknowledgements}

The authors would like to thank the technical staff at Applied Biosystems and Qiagen for their expertise.

\section{Authors' contributions}

HBB carried out the laboratory experiments, interpreted the results and wrote the manuscript. ABM co-interpreted the results and both authors read and approved the final manuscript.

\section{Competing interests}

The authors declare that they have no competing interests. 


\section{References}

1. Center for Disease Control: Water-related disease outbreaks. Morbid Mortal Weekly Report 1991-1992.

2. Griffin DW, Donaldson KA, Paul JH, Rose JB: Pathogenic human viruses in coastal waters. Clin Microbiol Rev 2003, 16(1):129-143.

3. Villegas LF: An improved method for detecting viruses in water. Presented at 2006 EPA Forum Washington, DC 2006.

4. Choi S, Jiang SC: Real time PCR quantification of human adenoviruses in urban rivers indicates genome prevalence but low infectivity. Appl and Enviro Microbio 2005, 7426-7433.

5. Dahling DR, Wright BA: Optimization of the BGM cell line culture and viral assay procedures for monitoring viruses in the environment. Appl and Enviro Microbiol 1986, 790-812.

6. Goldstein G, Guskey LE: Development of a shaker culture of buffalo green monkey kidney cells: Potential use for detection of enteroviruses. Appl and Enviro Microbiol 1982, 317-320.

7. Luker G, Chow C, Richards DF, Johnson FB: Suitability of infection of cells in suspension for detection of herpes simplex virus. J Clin Microbiol 1991, 1554-1557.

8. Reynolds KA, Gerba CP, Pepper IL: Detection of infectious enteroviruses by an integrated cell culture-PCR procedure. Appl and Enviro Microbiol 1996, 1424-1427.

9. Katzenelson EB, Fattal B, Hostovesky T: Organic flocculation: an efficient second-step concentration method for the detection of viruses in tap water. Appl Environ Microbiol 1976, 32:638-639.

10. Hoyt $J$, Margolin AB: Fortified sera and their use in environmental virology. Appl Environ Microbiol 2000, 66(6):2259-2262.

11. Jiang SC, Chu W: PCR detection of pathogenic viruses in southern California urban rivers. J Appl Microbiol 2004, 97(1):17-28.

doi:10.1186/1743-422X-7-282

Cite this article as: Balkin and Margolin: Detection of poliovirus by ICC/ qPCR in concentrated water samples has greater sensitivity and is less costly using BGM cells in suspension as compared to monolayers. Virology Journal 2010 7:282.

\section{Submit your next manuscript to BioMed Central and take full advantage of:}

- Convenient online submission

- Thorough peer review

- No space constraints or color figure charges

- Immediate publication on acceptance

- Inclusion in PubMed, CAS, Scopus and Google Scholar

- Research which is freely available for redistribution

Submit your manuscript at www.biomedcentral.com/submit
Biomed Central 